\title{
Visualizing Public Sector Accounting During the Pandemic Covid-19 by Android-based Augmented Reality
}

\author{
Imam Mulyono, Mika Marsely*, Annisa Fitriana \\ Accounting Department \\ State Polytechnic of Malang \\ Malang, Indonesia \\ mika.marsely@polinema.ac.id*
}

\begin{abstract}
Learning creativity has now become an important prerequisite for improving the standard of education in the COVID 19 pandemic situation. Obviously, all sectors of life have been affected by this epidemic, including higher education. Teaching is moving online on an untested and remarkable scale, and insufficient preparation has impeded online education, including networks, technological expertise, inaccessibility and unavailability issues, and weak digital skills. Thus, this study aims to use android-based augmented reality technology with the named of ARPUSEA (Augmented Reality on Public Sector Accounting) as the alternative to solve these problems. This research method was use research and development with the qualitative analysis. This research found that the students emerge a high level motivation and enjoy the learning due to the application. In addition, this research found so many advantages by using this application such as this application helped the students to understand the material so well due to the meaningful content and it can play repeatedly, reduced their cost of learning because this application was offline, and they are very excited to learn because the assessment was developed on game mode and the materials presented were very interesting, complete, detailed, and brief.
\end{abstract}

Keywords-public sector accounting, online learning, augmented reality, android, pandemic covid 19

\section{INTRODUCTION}

In most cases, prior to pre-COVID-19, the essence of accounting learning was governed by conventional learning [1], fitted with textbooks, whiteboards, PowerPoint, etc. Such phenomena lead to little enthusiasm for conventional learning [2] during the course, such as boredom and saturation, so the knowledge of transition does not go well. Then the coronavirus came and brought so many problems with learning, such as: lockdown [3], shocking lecturers, and students, online learning, internet issues, so many use of quota data, and less active students [1]. Lockdown would trigger a significant disruption in the learning of students [3] because neither the teacher nor the students were allowed to meet at all. After all, it was very risky to transmit the virus. So the all of education sector need resources to rebuild the loss in learning. In addition, the truth is that school activities do not always seem to keep up with the ways modern kids want to learn new things and exchange new ideas and knowledge with each other [4], such as the use of technology. This research argues that augmented reality may be an alternative to immersive and creative learning media to solve this.

Augmented Reality is a technology that blends the dimensions of two virtual objects or three dimensions and then projects these virtual objects in real time. By introducing virtual knowledge into the user world, Augmented Reality seeks to improve things for users. So many previous research about the use of augmented reality in any literature, but not for accounting topic that have not been done. Some researcher found that Augmented reality (AR) that were developed and tested are helpful in understanding complicated computer science concepts that the average student has a lot of trouble understanding on it [5]. Then, AR's student learning motivation was greater than using a textbook, so all the theory argues that technology has a potential effect on educational growth [6]. Furthermore, AR offers a learning environment that is connected to the formal classroom, so that learners can study outside of class hours and outside of school limits [7].

This research idea was to introduce students to a new learning environment that utilizes AR technology's ability to provide fascinating learning artifacts such as animation videos and games. Moreover, this research product is well associated with their experience with mobile technology and the fun they enjoy using this technology. Moreover, our product was aligned well with their. Furthermore, this research was intended to provide students with an AR learning environment based on simple and locally accessible facilities which could easily be incorporated into the accounting curricula of the public sector, requiring neither the physical transfer of students nor any special training for both the tangible components and the AR interface, except for a few picture markers seen during this COVID 19 pandemic by a computer or other system and a mobile device. 


\section{MethodS}

This research use research and development approach with this following step [8]. The first step is by collecting literature review and preliminary studies. The second step is the development by designing the application, material content, and build the application itself by Unity Software. The last is testing withhold on trial testing.

Before we hold on trial testing, we have been conducted a material and media testing for expert validation.

\section{A. Validation by Experts}

This study used primary data by questionnaire to infer the validity of ARPUSEA. The indicators validated by the suitability and the accuracy of the material and application attractiveness level. The questionnaire uses a Likert scale of 4. Criteria for each rating scale is score 4 for very clear, 3 for clear, 2 for unclear, and 1 for very unclear. The data analysis is by calculating the percentage, according to the formula:

$$
P=\frac{\sum x}{\sum x 1} \times 100 \%
$$

Notes:

$$
\begin{array}{ll}
\mathrm{P} & =\text { percentage } \\
\sum \mathrm{x} & =\text { Score of respondents' answer in } 1 \text { item } \\
\sum \mathrm{x} 1 & =\text { Maximum score in } 1 \text { item }
\end{array}
$$

To determine the conclusion, each item is validated by several criteria such as valid, valid enough, less valid and not valid. The score for each criteria can be seen in table 1 .

TABLE I. VALIDATION CRITERIA

\begin{tabular}{|l|l|}
\hline \multicolumn{1}{|c|}{ Answer } & \multicolumn{1}{c|}{ Criteria } \\
\hline $80-100$ & Valid \\
\hline $60-79$ & Quite Valid \\
\hline $40-59$ & Need Revision (Less Valid) \\
\hline $0-39$ & Need Revision (Not Valid) \\
\hline
\end{tabular}

The questionnaire was given to Public Sector Accounting lecturers as material experts and informatics engineering lecturers as media experts. The questionnaire also contains additional comments, criticisms, and suggestions from the validator regarding the application. The suggestions from the material and media expert's assessment then used to revise the application.

\section{B. Trial Testing to the Students}

After the application is validated by material and media experts, then the application is tested on students who have just finished taking Public Sector Accounting courses. This consideration was taken because the Odd semester 2020/2021 had not yet started when this research was done.
The trial testing was to analyze students' motivation and to assure that the interface is well function and use students feedback to decide how to improve system performance and usability. The motivation indicators refer to the Reduce Instructional Materials Motivation Survey (RIMMS) model [9] which describe into attention, relevance, confidence, and satisfaction then described in 12 statements. While the variables of interface functional (ease and enjoyment) were developed by the researcher itself into 8 statements. The measurement of each question / statement is carried out using a Likert scale of 1-4, where 4 shows very suitable responses, 3 is suitable, 2 is not suitable, and 1 is not suitable.

\section{RESULTS AND ANALYSIS}

ARPUSEA (Augmented Reality On Public Sector Accounting) is an android-based learning application in the Public Sector Accounting course which discusses the topic "Accounting for Non-Profit Entities" that refer to the latest accounting standards, namely ISAK 35. Broadly speaking, Public Sector Accounting is divided into 2 major themes, first accounting for non-profit entities and second accounting for government. ARPUSEA is actually a prototype which will later be developed again for government accounting materials. In actually, ARPUSEA display so many visualize material such as 2D video, pdf file, animation, game and matching answer between the answers that have been done by students and the answer keys that are already available in the ARPUSEA. In addition, this application was made on offline mode in order to the students can play that repeatedly to fully understanding the material. The other consideration was to resolve the costly learning problems during the pandemic covid, because the students have to spend a lot of quota data to follow the learning process from other courses or lecturer.

Differ from previous research by most science researchers such as Tomara and Gouscos [9], Uematsu and Saito [10] and Peterson et al [11] that stated the textual information to guide and provide educational content in the expected AR approach sometimes may act as a disruptive. In order to explain the students' comprehension, this research product contains so many textual contents as an interpretation of the animated image. So this study claims that this was only due to the distinctive attribute between social science and precise science.

ARPUSEA was developed to allow for the augmentation of non-profit organizations accounting in simple ways. First, the mobile camera scanning the images marker on the laptop/gadget screen, then the application augments them with the 2D animation video, pdf file, and game. There are seven markers on the ARPUSEA, which are five markers containing the content of the 2D animation video and pdf file, and the next two markers contain the quiz in game form and the last is given with matching answers from the case study. In addition to the interesting animated video to demonstrate the content, we developed the application in the form of gamification to render the assessment. In the game, 20 questions were given, and according to the predetermined time, each student must answer the questions. The screen would then display the ratings of all 
respondents who responded. In this scenario, in answering the questions, the rating of the participant can differ according to its accuracy and speed. The three winners will be chosen at the end of the game and shown on the scoreboard. From a technological point of view, the program creates a vision-based AR [10] that is used for image recognition and only arranges augmented data for users after pointing their device to the image marker. The application was programmed in CSharp and configured to run on mobile android platforms (smartphones and tablets) with a minimum API level of 18 (Android 4.3 "Jellybean"). As the development framework, Unity 3D 5.4.03 was used since several specific development tools were provided, including the Unity $3 \mathrm{D}$ plugin for AR development.

First of all, the validation process takes on the material and media experts before doing field testing, to get an evaluation and feedback if changes are required. This table below shows the results of a media and content validation specialist.

TABLE II. MATERIAL VALIDATION TEST RESULTS

\begin{tabular}{|c|c|c|c|c|c|}
\hline \multirow[t]{2}{*}{ No. } & \multirow[t]{2}{*}{ Statements } & \multicolumn{2}{|c|}{ Score } & \multirow{2}{*}{$\begin{array}{c}\text { Percentage } \\
(\%)\end{array}$} & \multirow[t]{2}{*}{ Result } \\
\hline & & $X$ & $X 1$ & & \\
\hline 1. & The display attracts attention & 3 & & 75 & $\begin{array}{l}\text { Quite } \\
\text { Valid }\end{array}$ \\
\hline 2. & $\begin{array}{l}\text { The letters in the application } \\
\text { can be read clearly }\end{array}$ & 4 & & 100 & Valid \\
\hline 3. & $\begin{array}{l}\text { Compatibility of fonts on the } \\
\text { media (fonts form) }\end{array}$ & 3 & & 75 & $\begin{array}{l}\text { Quite } \\
\text { Valid }\end{array}$ \\
\hline 4. & $\begin{array}{l}\text { The compatibility of the } \\
\text { color }\end{array}$ & 3 & & 75 & $\begin{array}{l}\text { Quite } \\
\text { Valid }\end{array}$ \\
\hline 5. & $\begin{array}{l}\text { The simplicity of the } \\
\text { application layout so that the } \\
\text { material is easy to } \\
\text { understand }\end{array}$ & 4 & & 100 & Valid \\
\hline 6. & Text and figure composition & 3 & & 75 & $\begin{array}{l}\text { Quite } \\
\text { Valid }\end{array}$ \\
\hline 7. & $\begin{array}{l}\text { Selection of background } \\
\text { settings }\end{array}$ & 3 & & 75 & $\begin{array}{l}\text { Quite } \\
\text { Valid }\end{array}$ \\
\hline 8. & $\begin{array}{l}\text { Placement of supporting } \\
\text { video material }\end{array}$ & 3 & & 75 & $\begin{array}{l}\text { Quite } \\
\text { Valid }\end{array}$ \\
\hline 9. & $\begin{array}{lcc}\text { Selection f image } & \text { as } \\
\text { supporting material } & \end{array}$ & 4 & & 100 & Valid \\
\hline 10. & $\begin{array}{l}\text { Message design is relevant } \\
\text { to content }\end{array}$ & 4 & & 100 & Valid \\
\hline 11. & $\begin{array}{l}\text { Application can be run on } \\
\text { smartphone properly }\end{array}$ & 3 & & 75 & $\begin{array}{l}\text { Quite } \\
\text { Valid }\end{array}$ \\
\hline
\end{tabular}

Table 2 shows the results of the material validation test. Based on the results of the validation test, all question items were declared valid by material experts, so they did not require revision. The material validator's comment is that the material content is very good overall and in line with the subject learning outcomes (CPMK). With the range of media used, namely animated video, audio plus pdf, word, excel files, it is believed that it will enable students to understand Public Sector Accounting material more easily, particularly for the subject of Accounting for Non-profit Entities. The material validator often assumes that the presented material is very complete and is briefly presented, point by point. A succinct and not wordy presentation with an attractive appearance helps learners not bored with learning and makes the content easier to understand.

TABLE III. MEDIA VALIDATION TEST RESUlts

\begin{tabular}{|c|c|c|c|c|c|}
\hline \multirow[t]{2}{*}{ No. } & \multirow[t]{2}{*}{ Statements } & \multicolumn{2}{|c|}{ Score } & \multirow{2}{*}{$\begin{array}{c}\text { Percentage } \\
(\%)\end{array}$} & \multirow[t]{2}{*}{ Result } \\
\hline & & $X$ & $X 1$ & & \\
\hline 1. & $\begin{array}{l}\text { The suitability of material } \\
\text { materials with Subject } \\
\text { Learning Outcomes (CPMK) }\end{array}$ & 4 & & 100 & Valid \\
\hline 2. & $\begin{array}{l}\text { The suitability of the video } \\
\text { given in the application }\end{array}$ & 4 & & 100 & Valid \\
\hline 3. & $\begin{array}{l}\text { The suitability of the } \\
\text { description (audio) given in } \\
\text { the application }\end{array}$ & 4 & & 100 & Valid \\
\hline 4. & $\begin{array}{l}\text { Completeness of the material } \\
\text { in the application }\end{array}$ & 4 & & 100 & Valid \\
\hline 5. & $\begin{array}{l}\text { The application was very } \\
\text { interesting }\end{array}$ & 4 & & 100 & Valid \\
\hline 6. & $\begin{array}{l}\text { Ease of understanding the } \\
\text { material }\end{array}$ & 4 & & 100 & Valid \\
\hline 7. & $\begin{array}{l}\text { The relationship between } \\
\text { concepts in the application }\end{array}$ & 4 & & 100 & Valid \\
\hline 8. & In-app enrichment & 4 & & 100 & Valid \\
\hline 9. & $\begin{array}{l}\text { Grammar used in the } \\
\text { application }\end{array}$ & 4 & & 100 & Valid \\
\hline 10. & $\begin{array}{l}\text { The suitability of material } \\
\text { materials with Subject } \\
\text { Learning Outcomes (CPMK) }\end{array}$ & 4 & & 100 & Valid \\
\hline
\end{tabular}

Table 3 shows the results of the media validation test. Based on the results of the validation test, there were 7 question items that were declared valid enough and 4 question items that were declared valid by media experts so that this application did not require revision. The media validator argued that the established application was good and very appropriate for distance learning, as all teaching and learning activities need to be performed online at the moment. The presence of ARPUSEA learning media will save costs (internet quota) for both lecturers and students compared to the synchronous learning model, namely through zoom meetings, google meetings, etc. Moreover, the memory needed by this application, namely $94,96 \mathrm{MB}$, is not too big, so that most of it will feel light running on student smartphones. The presence of an attractive application that selects the right design, color, writing, image and context also really helps students to retain their focus when learning.

The next stage is product testing, after receiving validation from content and media experts, to assess learning motivation after using this application, then student responses to the functional interface of using the application. Students who have just finished taking Public Sector Accounting courses have completed the trial testing and when this study was conducted, the Odd Semester 2020/2021 had not yet begun. First, the author sends all image marker files and QR codes to participants to smooth out the field testing process. The researcher then offers participants an overview of the purpose of field research and how to use the technology in a video that has been posted on YouTube and the manual guidance for using the application. After the technical guidelines for using 
the application are understood by all participants, the field testing process starts immediately. The students will scan this QR Code for the installation procedure.

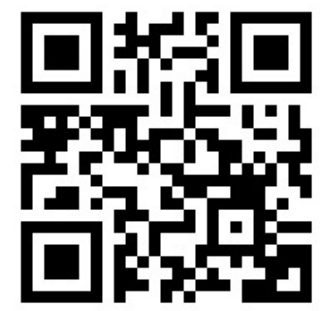

Fig. 1. Application QR Code

Again, this figure below shows us the condition of field testing on online learning, where teachers and students work from their own homes.
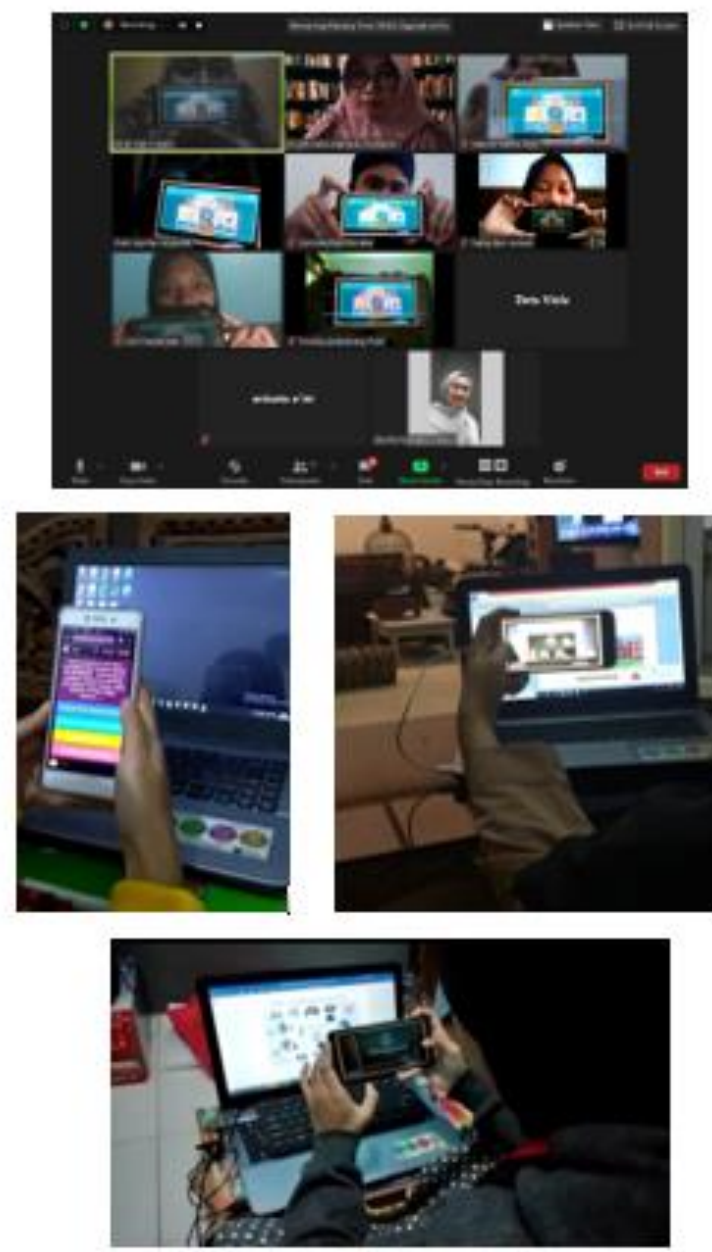

Fig. 2. Field testing.

In this study, 4 indicators were used to assess learning motivation, namely: attention, importance, trust, and satisfaction, as shown in the table 4 below.
TABLE IV. ITEMS IN THE RIMMS (REDUCE INSTRUCTIONAL MATERIALS MOTIVATION SURVEY)

\begin{tabular}{|c|c|c|}
\hline No. & Items & Dimensions \\
\hline 1. & $\begin{array}{l}\text { The quality of the AR application } \\
\text { helped to hold my attention. }\end{array}$ & Attention \\
\hline 2. & $\begin{array}{l}\text { The way the information is arranged } \\
\text { on the interface of the AR application } \\
\text { helped keep my attention. }\end{array}$ & Attention \\
\hline 3. & $\begin{array}{l}\text { The variety of content, graphics, text, } \\
\text { etc., helped keep my attention on the } \\
\text { user instructions. }\end{array}$ & Attention \\
\hline 4. & $\begin{array}{l}\text { It is clear to me how the content of this } \\
\text { learning material is related to things I } \\
\text { already know. }\end{array}$ & Relevance \\
\hline 5. & $\begin{array}{l}\text { The content and presentation style in } \\
\text { this lesson convey the impression that } \\
\text { its content is worth knowing. }\end{array}$ & Relevance \\
\hline 6. & $\begin{array}{l}\text { The content of this lesson will be } \\
\text { useful to me }\end{array}$ & Relevance \\
\hline 7. & $\begin{array}{l}\text { As I worked on this lesson, I was } \\
\text { confident that I could learn the content. }\end{array}$ & Confidence \\
\hline 8. & $\begin{array}{l}\text { After working on this lesson for a } \\
\text { while, I was confident that I would be } \\
\text { able to pass a test on it. }\end{array}$ & Confidence \\
\hline 9. & $\begin{array}{l}\text { The good organization of the content } \\
\text { helped me be confident that I would } \\
\text { learn this material. }\end{array}$ & Confidence \\
\hline 10. & $\begin{array}{l}\text { I enjoyed this lesson so much that I } \\
\text { would like to learn more about this } \\
\text { subject. }\end{array}$ & Satisfaction \\
\hline 11. & I really enjoyed working on this lesson. & Satisfaction \\
\hline 12. & $\begin{array}{l}\text { It was a pleasure to work on such well- } \\
\text { designed lesson. }\end{array}$ & Satisfaction \\
\hline
\end{tabular}

This field testing was conducted on students who had just finished taking Public Sector Accounting courses. Table 4 shows the results of the limited field trials. From the 1-4 Likert scale, the results are as shown in Table 4 besides.

TABLE V. The Field Testing Result (Motivation)

\begin{tabular}{|l|l|l|l|}
\hline \multicolumn{1}{|c|}{ Items } & \multicolumn{1}{c|}{ Min } & \multicolumn{1}{c|}{ Max } & Mean Score \\
\hline Attention & 3.67 & 3.83 & 3.75 \\
\hline Relevance & 3.75 & 3.83 & 3.78 \\
\hline Confidence & 3.58 & 3.83 & 3.66 \\
\hline Satisfaction & 3.58 & 3.67 & 3.64 \\
\hline Total & 3.58 & 3.67 & 3.69 \\
\hline
\end{tabular}

Table 5 summarizes the motivational findings based on the average score for each of the four subscales of the RIMMS. The mean score was 3.75 in the attention aspect, indicating that the attention levels were upper-medium, which means that the appearance of the application kept their attention focused on the content explanation. The mean score was 3.78 in the relevance aspect, which suggests that students were very reassured that the learning materials were important to their interest because the design of material content used a straightforward description that was directly connected to their lives. The mean score was 3.66 in the trust aspect, implying a degree of confidence well above average. After learning the material on this app, the learners felt that they were able to get good results on the tests/quizzes/assignments. Last, the mean 
score was 3.64 in the satisfaction aspect. This study may thus conclude that students are satisfied with the experience during field training. The respondents reported that after using this program, ARPUSEA, they were happier, more interested and enthusiastic about learning about Public Sector Accounting.

TABLE VI. The Field TeSting Result (EASE AND ENJOYMENT)

\begin{tabular}{|l|l|l|}
\hline Items & \multicolumn{1}{|c|}{ Ease indicators } & Mean Score \\
\hline 1. & The mobile device can detect the marker well & 3.75 \\
\hline 2. & $\begin{array}{l}\text { The scanning marker able to show the material } \\
\text { well }\end{array}$ & 3.83 \\
\hline $\begin{array}{l}\text { The menu in the application makes me easier to } \\
\text { understand the material }\end{array}$ & 3.75 \\
\hline 3. & The application is easy to use & 3.58 \\
\hline Items & \multicolumn{1}{|c|}{ Enjoyment indicators } & Mean Score \\
\hline 1. & $\begin{array}{l}\text { The enjoyment during the used of the mobile } \\
\text { device }\end{array}$ & 3.67 \\
\hline 2. & $\begin{array}{l}\text { The material presented in the application is } \\
\text { accordance with students needs }\end{array}$ & 3.75 \\
\hline 3. & $\begin{array}{l}\text { The application menu interface was attractive } \\
\text { The application design and colour was } \\
\text { interesting }\end{array}$ & 3.42 \\
\hline 4. & \multicolumn{2}{|c|}{} \\
\hline
\end{tabular}

The responses of the students concerning the extent of ease and pleasure in using the application are provided in the above table 6. Most of the respondents suggested that they have almost no trouble using mobile devices during field tests $(M=3.75)$ and that their mobile phone camera is very consistent with all content display markers $(M=3.83)$. They claim that the application makes the Public Sector Accounting content easier to grasp $(M=3.75)$. Overall, they said that it was easy to use this application $(M=3.58)$. Students, on the other hand, demonstrated a high-level experience of using mobile devices $(M=3.67)$ and the content provided in the application meets their needs $(M=3.75)$. Finally, the learners claimed that the interface of the application menu was very appealing (3.42) and that the design and color of the application were absolutely fascinating $(\mathrm{M}=3.5)$.

\section{DISCUSSION}

With respect to the reaction of the students during the AR learning field research, this study found that they responded with enthusiasm, followed instructions easily, and suggested that using mobile devices as a learning tool is very comfortable. They easily adapted to the new conditions and followed the directions without doubting the use of the mobile device or the scanning of the marker. he appropriate design of digital learning will increase the positive emotions and motivation of students and help the learning process in advance [12].

Based on the results of the testimonials, the majority of respondents felt that this was the first time they had learned to use an application like ARPUSEA, but while this was new to them, they did not experience any obstacles. They claim that the animated video content shown in the application is very imaginative, accompanied by a very appealing visual appearance, so that when viewing and listening to the material, students would not feel bored. The length of the video is also not considered too long, which is a series of 7-15 minutes that helps students to correctly capture the content since the material is presented very concisely and fully. In addition to the explanation of the material in the form of an With the presentation of the pdf file, the clarification is also applied to the animated video, so that the respondents feel that the material shown is quite full and very detailed. When they do quizzes, respondents often feel relaxed because the quizzes are packaged in the form of a game so that students feel delighted that they can compete with their peers, not nervous and fearful of doing quizzes. It was aligned with the statement of Gopalan et al [13] that using technology and social media's $[14,15]$ is a rather familiar medium for the $\mathrm{Z}$ generations, consistent with that. Finally, the respondents also thought in accounting terms that this application was quite creative, so that students were more enthusiastic about learning about accounting in the public sector.

This study finds so many benefits from the AR online learning process that students get from the AR application. First, the students said that this application helped them understand the content very well. This result was consistent with the study [16] that the AR application was designed to be interesting, easy to use and beneficial for students to confidently understand the learning materials. Second, their learning costs have been minimized by this program since this application was offline. This study contradicted the finding of Peterson [11] that AR was costly, so that only a few students at a time could participate in the module. Third, they love this application so much because if they haven't understood the content, they can play it repeatedly. Fourth, since the evaluation was established in the game mode, they are really excited. Finally, they argue that the materials presented were really interesting, complete, detailed, and short, so it made it easier to understand and enjoy the learning of the subject.

\section{CONCLUSION}

Not only for pandemic learning, but also for face-to-face learning in normal situations, Augmented Reality and mobile technology is quite fitting. For educational purposes, AR and mobile technology can be leveraged in Public Sector Accounting curricula to synchronize with millennials' desires and ways of learning and interacting. In order to improve and provide a clear interpretation of the principles of Public Sector Accounting, the AR learning experiences did not require special equipment or physical transfer of students, but were easily incorporated into Public Sector Accounting curricula. This study believe that such experiments would be able to offer students more engaging, enjoyable and productive learning experiences. In a future research, this study will be developed into other public sector accounting content, such as local government accounting, in order to experience the conceptual barriers and provide full conceptions in the thinking of students about key concepts in public sector learning. In order to assess 
the possible effect of $\mathrm{AR}$, future research is required to evaluate learning outcomes.

\section{REFERENCES}

[1] A. Sangster, G. Stoner, and B. Flood, "Insights into accounting education in a COVID-19 world," Account. Educ., vol. 29, no. 5, pp. 431-562, 2020.

[2] M. Prensky, "Digital natives, digital immigrants part 2: Do they really think differently?," Horiz., 2001.

[3] S. Burgess and H.H. Sievertsen, "Schools, skills, and learning: The impact of COVID-19 on education." 2020

[4] D. Oblinger, "The next generation of educational engagement," J. Interact. media Educ., vol. 2004, no. 1, 2004.

[5] R. Budiman, "Developing learning media based on augmented reality (AR) to improve learning motivation," J. Educ. Teach. Learn., vol. 1, no. 2, pp. 89-94, 2016.

[6] N.F. Saidin, N.D.A. Halim, and N. Yahaya, "A review of research on augmented reality in education: Advantages and applications," Int. Educ. Stud., vol. 8, no. 13, pp. 1-8, 2015.

[7] S.S. Nana, "Metode Penelitian Pendidikan Bandung: PT Remaja." Rosdakarya, 2007

[8] M. Tomara and D. Gouscos, "A Case Study: Visualizing Coulomb Forces With the Aid of Augmented Reality," J. Educ. Comput. Res., vol. 57, no. 7, pp. 1626-1642, 2019.
[9] R.K. Sungkur, A. Panchoo, and N.K. Bhoyroo, "Augmented reality, the future of contextual mobile learning," Interact. Technol. Smart Educ. 2016

[10] E.P. Burton, W. Frazier, L. Annetta, R. Lamb, R. Cheng, and M. Chmiel, "Modeling augmented reality games with preservice elementary and secondary science teachers," J. Technol. Teach. Educ., vol. 19, no. 3, pp. 303-329, 2011

[11] Y. Uematsu and H. Saito, Vision-based augmented reality applications. InTech, 2008

[12] C.N. Peterson, S.Z. Tavana, O.P. Akinleye, W.H. Johnson, and M.B. Berkmen, "An idea to explore: Use of augmented reality for teaching three-dimensional biomolecular structures," Biochem. Mol. Biol. Educ., vol. 48, no. 3, pp. 276-282, 2020.

[13] S.Y. Al-Imamy, "Blending printed texts with digital resources through augmented reality interaction,” Educ. Inf. Technol., pp. 1-16, 2019.

[14] V. Gopalan, A.N. Zulkifli, and J.A.A. Bakar, "A learning performance study between the conventional approach and augmented reality textbook among secondary school students," in AIP Conference Proceedings, 2016, vol. 1761, no. 1, p. 20039.

[15] M.P. Arnone, R. V Small, S.A. Chauncey, and H.P. McKenna, "Curiosity, interest and engagement in technology-pervasive learning environments: a new research agenda," Educ. Technol. Res. Dev., vol. 59, no. 2, pp. 181-198, 2011.

[16] J.P. Preston, L. Moffatt, S. Wiebe, A. McAuley, B. Campbell, and M. Gabriel, "The use of technology in Prince Edward Island (Canada) high schools: Perceptions of school leaders," Educ. Manag. Adm. Leadersh., vol. 43, no. 6, pp. 989-1005, 2015. 